\title{
Encapsulated Hydrogels by E-beam Lithography and Their Use in Enzyme Cascade Reactions
}

Rock J. Mancini ${ }^{\dagger}$, Samantha J. Paluck, Erhan Bat and Heather D. Maynard*

Department of Chemistry and Biochemistry and California NanoSystems Institute, University of California, Los Angeles, 607 Charles E. Young Drive East, Los Angeles, California 90095-1569

\section{Supporting Information}

\section{Materials}

All solvents were purchased from Fisher Scientific (Pittsburgh, PA) and used without further purification unless otherwise noted. Poly(ethylene glycol) and 8-arm amine terminated poly(ethylene glycol) were purchased from JenKem Inc. Amplex Red, Alexa Fluor 488 and Maleimide-Coumarin were purchased from Invitrogen. Silicon wafers were purchased from University Wafers (Boston, MA). All other reagents including horseradish peroxidase and glucose oxidase were purchased from Sigma-Aldrich. PEG-biotin and PEG-AO were synthesized according to literature procedures. ${ }^{1}$ Imidazole-1-sulfonyl chloride was synthesized following a literature procudure. ${ }^{2}$ 


\section{Analytical Techniques}

NMR spectra were recorded on Bruker Avance $500 \mathrm{MHz}$ or $400 \mathrm{MHz}$ spectrometers. UVVisible spectroscopy was performed with a BioMate 5 Spectrophotometer (Thermo Spectronic Instruments). Infrared spectra were obtained with a Perkin-Elmer Spectrum One instrument equipped with a universal ATR accessory.

\section{2,5-Dioxopyrrolidin-1-yl pent-4-ynoate}

To a flame dried round bottom flask containing $100 \mathrm{~mL}$ of freshly distilled methylene chloride (DCM) was added $N$-hydroxysuccinimide (NHS) (1.0 g, $8.7 \mathrm{mmol}, 1 \mathrm{eq})$, pentynoic acid (0.94 g, $9.6 \mathrm{mmol}, 1.1 \mathrm{eq})$, triethylamine (TEA) (1.4 g, $14 \mathrm{mmol}, 1.6 \mathrm{eq})$, and 4-dimethylaminopyridine (DMAP) (0.11 g, $0.87 \mathrm{mmol}, 0.1 \mathrm{eq})$. The resulting solution was stirred for $30 \mathrm{~min}$ before addition of 1-ethyl-3-(3-dimethylaminopropyl) carbodiimide (EDC) (1.8 g, $9.6 \mathrm{mmol}, 1.1 \mathrm{eq}$ ). The reaction was stirred for $4 \mathrm{~h}$ at $22^{\circ} \mathrm{C}$, and the solvent was removed in vacuo to give a crude product which was subjected to column chromatography $\left(100 \%\right.$ dichloromethane - DCM, $R_{\mathrm{f}}$ 0.4). This product was further purified by recrystallization from $1: 4$ ethyl acetate : hexanes to obtain the title compound as a white solid (0.69 g, 40\% yield). ${ }^{1} \mathrm{H}$ NMR (500 $\left.\mathrm{MHz}, \mathrm{CDCl}_{3}\right) \delta$ : 2.90-2.84 (m, 6H), $2.62(\mathrm{dt}, 2 \mathrm{H}, J=7.5,2.6 \mathrm{~Hz}), 2.05(\mathrm{t}, 1 \mathrm{H}, J=2.6 \mathrm{~Hz}) ;{ }^{13} \mathrm{C} \mathrm{NMR}(400 \mathrm{MHz}$; $\left.\mathrm{CDCl}_{3}\right) \delta(\mathrm{ppm}): 169.1,167.2,81.0,70.2,30.4,25.7,14.2 ;$ DEPT-135 ${ }^{13} \mathrm{C}\left(400 \mathrm{MHz} ; \mathrm{CDCl}_{3}\right)$ $\delta(\mathrm{ppm}):$ 69.9(-), 30.18(+), 25.5(+), 14.0(+) ppm. FTIR $v_{\max } / \mathrm{cm}^{-1}: 3304,2948,2258,1815,1787$, $1734,1430,1415,1371,1203,1085,1067,993,906$. 


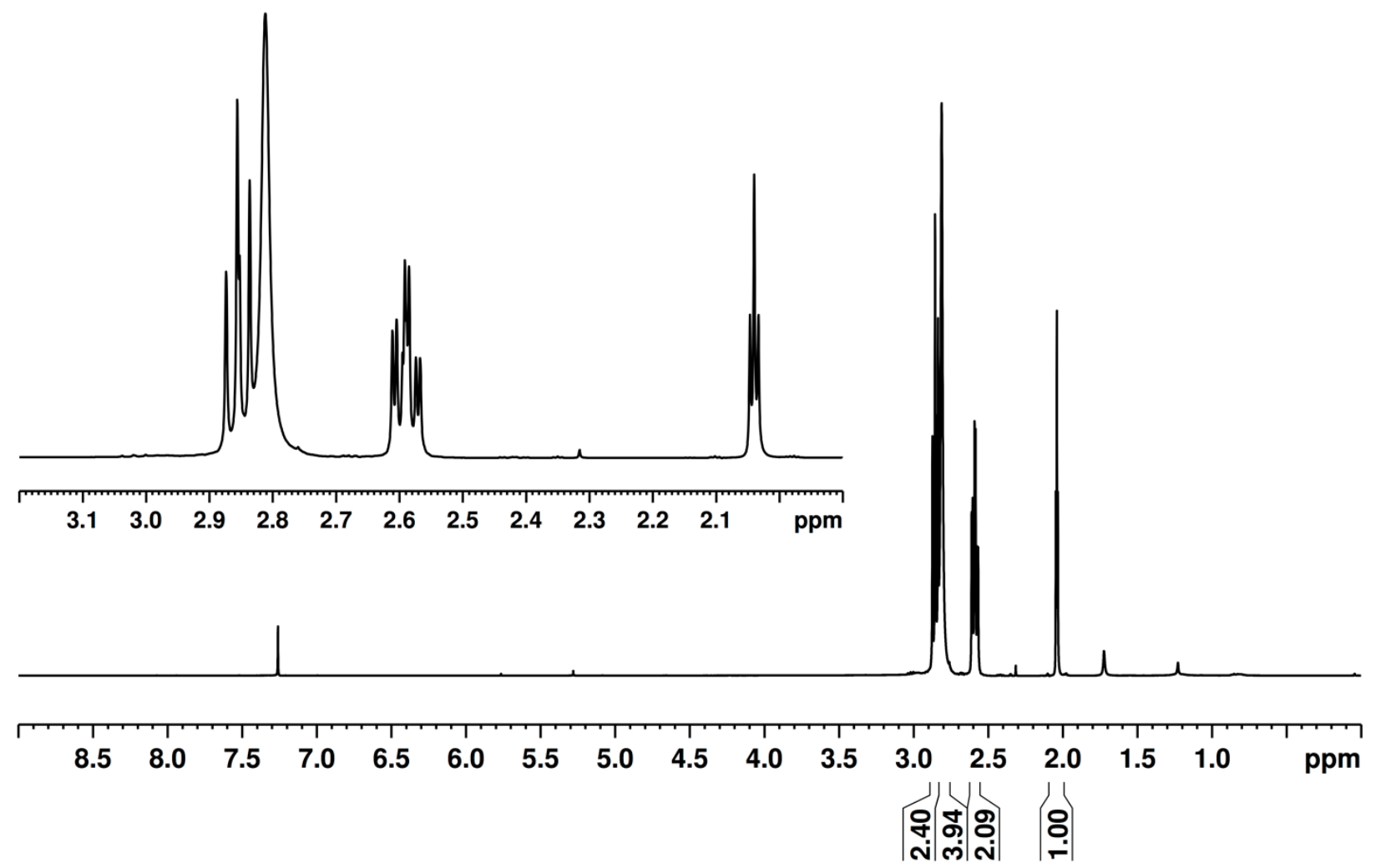

Figure S1. ${ }^{1} \mathrm{H} \mathrm{NMR}\left(500 \mathrm{MHz}, \mathrm{CDCl}_{3}\right)$ of 2,5-Dioxopyrrolidin-1-yl pent-4-ynoate

\section{N-Hydroxy Succinimidyl Levulinate}

This compound was synthesized similarly to a known procedure. ${ }^{3}$ To a flame dried round bottom flask containing $100 \mathrm{~mL}$ of freshly distilled DCM was added levulinic acid (1.0 g, 8.6 mmol, 1 eq), NHS (1.1 g, 9.5 mmol, $1.1 \mathrm{eq})$, TEA (1.7 g, $17 \mathrm{mmol}, 2 \mathrm{eq})$, and DMAP (0.11 g, $0.86 \mathrm{mmol}, 0.1 \mathrm{eq})$. The resulting solution was cooled to $0^{\circ} \mathrm{C}$ and stirred for $30 \mathrm{~min}$ before addition of N,N'-dicyclohexylcarbodiimide (DCC) (1.8 g, $9.5 \mathrm{mmol}, 1.1 \mathrm{eq})$. The reaction was warmed to room temperature and stirred for an additional $6 \mathrm{~h}$. The crude reaction mixture was added to ethyl acetate previously cooled to $-20^{\circ} \mathrm{C}$. The white precipitate was filtered off and 
ethyl acetate removed in vacuo. The reaction product was then purified by silica gel column chromatography $\left(2.5 \% \mathrm{MeOH}\right.$ in $\left.\mathrm{CHCl}_{3}\right)$ to obtain the purified product as a white solid $(0.95 \mathrm{~g}$, $52 \%$ yield). Small aliquots ( $10 \mathrm{mg})$ of the title compound were further purified by sublimation (0.02 Torr, $\left.60^{\circ} \mathrm{C}\right)$ prior to use. ${ }^{1} \mathrm{H}$ NMR $\left(400 \mathrm{MHz}, \mathrm{CDCl}_{3}\right) \delta: 2.81(\mathrm{~m}, 4 \mathrm{H}), 2.77(\mathrm{~m}, 4 \mathrm{H}), 2.14$ (m, 3H). ${ }^{13} \mathrm{C}$ NMR (400 MHz, $\mathrm{CDCl}_{3}$ ) \&: 205.1, 169.2, 168.2, 37.5, 29.6, 25.6, 25.0 ppm.

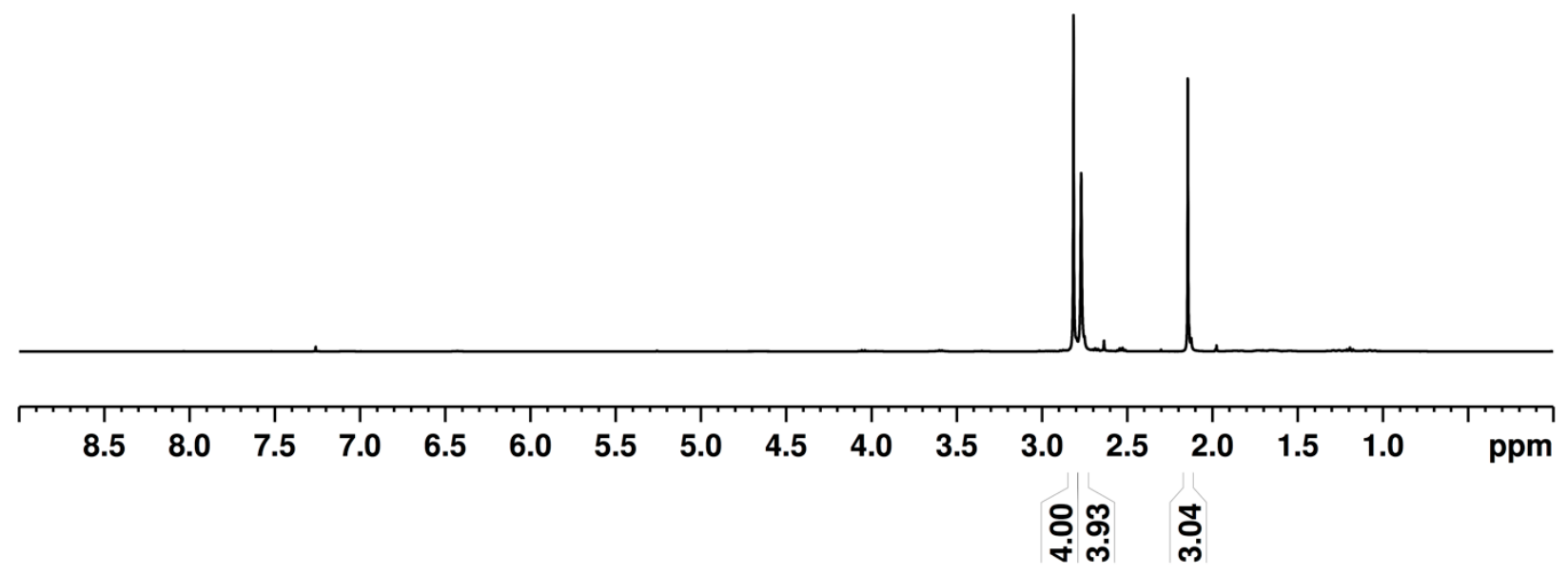

Figure S2. ${ }^{1} \mathrm{H}$ NMR (400 MHz, $\mathrm{CDCl}_{3}$ ) of $\mathrm{N}$-hydroxy succinimidyl levulinate

\section{Alkyne-Poly(ethylene glycol) (Alkyne-PEG)}

Amine-terminated 8-arm PEG (10.9 $\mathrm{kDa}$ or $20 \mathrm{kDa}, 20 \mathrm{mg} / \mathrm{mL}$ ) was added to a solution of 2,5dioxopyrrolidin-1-yl pent-4-ynoate $(5 \mathrm{mg} / \mathrm{mL})$ in $\mathrm{DCM}$ and allowed to react for $1 \mathrm{~h}$ at $23^{\circ} \mathrm{C}$. The solvent was removed in vacuo. The crude product was then re-dissolved in Milli-Q water and purified by centrifugal filtration $\left(3,000 \mathrm{MWCO}\right.$, Milli-Q $\left.\mathrm{H}_{2} \mathrm{O}\right)$ followed by lyophilization to isolate the pure product as a white solid. ${ }^{1} \mathrm{H}$ NMR $\left(500 \mathrm{MHz}, \mathrm{CDCl}_{3}\right) \delta: 3.80-3.83$ (t, $\mathrm{NCH}$, 
2H), 3.64-3.49 (m, PEG peaks), 2.50-2.55 (td, 2H), 2.39-2.43 (t, 2H), 2.01-2.02 (t, CCH, 1H). Percent substitution was calculated to be $90 \%$ by comparing the integrations of the alkyne endgroup with the $\mathrm{CH}_{2} \mathrm{CH}_{2}$ peak of the PEG backbone. FTIR $v_{\text {max }} / \mathrm{cm}^{-1}: 3312,2881,2123,1656$, 1464, 1337, 1279, 1239, 1057, 960, 842 .

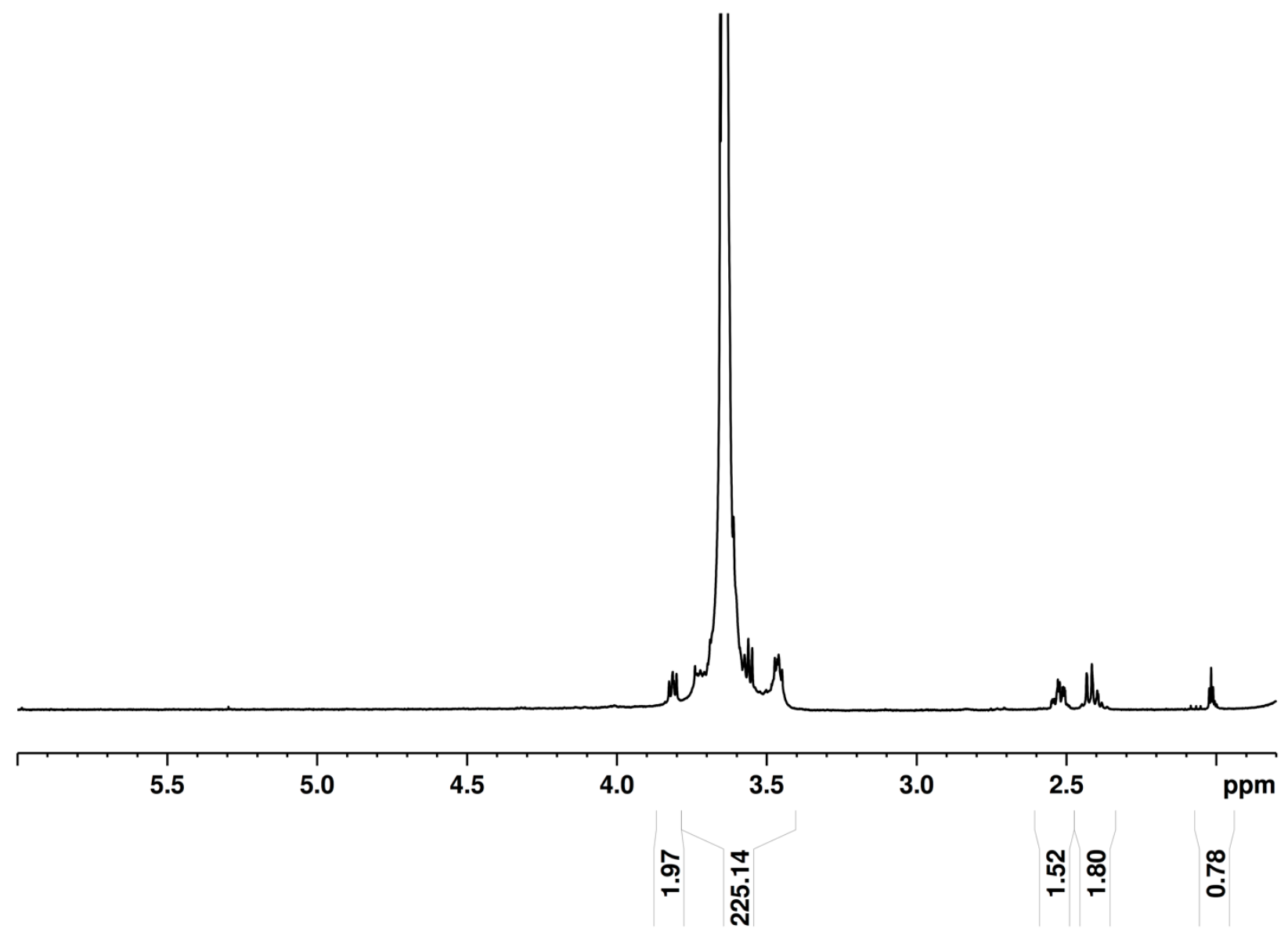

Figure S3. ${ }^{1} \mathrm{H}$ NMR $\left(500 \mathrm{MHz}, \mathrm{CDCl}_{3}\right.$ ) of alkyne poly(ethylene glycol) 


\section{Levulinyl Horseradish Peroxidase Marina Blue Conjugate (Lev-HRP-MB)}

Horseradish Peroxidase (1 mg, $1 \mathrm{mg} / \mathrm{mL}$, Dulbecco's phosphate buffered saline - DPBS pH 7.4) was combined with NHS levulinate (3 eq, as a $0.1 \mathrm{mg} / \mathrm{mL}$ solution in DMSO) and the reaction was stored at $4^{\circ} \mathrm{C}$ for $24 \mathrm{~h}$. The crude reaction mixture was purified by centriprep ultracentrifugation (MWCO $3 \mathrm{kDa}$ against DPBS, pH 7.4) to a final volume of $1 \mathrm{~mL}$ in $100 \mathrm{mM}$ PB, $\mathrm{pH}$ 8.0. Degree of labeling was determined by reaction with Alexafluor 488 hydrazide. A $100 \mu \mathrm{L}$ aliquot of the purified conjugate was combined with Alexafluor 488 hydrazide $(40 \mu \mathrm{L}$, $1 \mathrm{mg} / \mathrm{mL}$ in $\mathrm{DMF}$ ), and the reaction was stored for $24 \mathrm{~h}$ at $4^{\circ} \mathrm{C}$. The crude reaction mixture was purified by centriprep ultra-centrifugation (MWCO 3kDa against DPBS, $\mathrm{pH} 7.4$ ) to a final volume of $100 \mu \mathrm{L}$. Degree of labeling was determined to be 1.00 by comparing the protein absorbance at $280 \mathrm{~nm}$ to the fluorophore absorbance at $490 \mathrm{~nm}$ with a correlation factor of 0.11 for the fluorophore. Next $40 \mu \mathrm{L}$ of Marina Blue NHS ester $(5 \mathrm{mg} / \mathrm{mL}$ in DMSO) was added to the purified conjugate solution and the reaction mixture was stored at room temperature for $3 \mathrm{~h}$ before a second addition of $40 \mu \mathrm{L}$ of Marina Blue NHS ester $(5 \mathrm{mg} / \mathrm{mL}$ in DMSO). The mixture was held at $4^{\circ} \mathrm{C}$ for $24 \mathrm{~h}$ and then purified by centriprep ultra-filtration ( $3 \mathrm{kDa}$ MWCO against DPBS, pH 7.4) before dilution to a final volume of $0.5 \mathrm{~mL}$. Activity retention was confirmed by reaction with Amplex Red $(50 \mu \mathrm{M})$ and $100 \mathrm{ppm}$ hydrogen peroxide. Fluorophore degree of labeling was determined to be 0.68 based on the relative absorbance of the conjugate at $350 \mathrm{~nm}$ relative to absorbance of the native protein at $280 \mathrm{~nm}$.

\section{Azido Glucose Oxidase Alexafluor 488 Conjugate (Azide-GOX-AF488)}

Glucose Oxidase was prepared at a concentration of $1 \mathrm{mg} / \mathrm{mL}$ in DPBS, $\mathrm{pH}$ 7.4. The enzyme was modified to contain free azide moieties similar to reported procedures with imidazole-1- 
sulfonyl azide hydrochloride ${ }^{2,4}$ except in this case only 3 equivalents of the diazo transfer reagent were added. (Caution with this potentially explosive procedure). The reaction mixture was purified by centriprep ultra-centrifugation (MWCO $3 \mathrm{kDa}$ against DPBS, $\mathrm{pH}$ 7.4) to a final volume of $0.5 \mathrm{~mL}$ and the modified protein was assayed for azide moieties. An aliquot of the modified GOX $(100 \mu \mathrm{L})$ was incubated with Alexafluor 594 Click It ${ }^{\circledR}$ alkyne $(20 \mu \mathrm{L}, 1 \mathrm{mg} / \mathrm{mL}$, DMSO). Degree of labeling was determined to be 1.4 azides per protein by comparing the relative UV absorbance of the protein at $280 \mathrm{~nm}$ to that of the dye at $590 \mathrm{~nm}$ with a correlation factor of 0.56 for the dye. Next, the modified protein $(0.8 \mathrm{mg}, 2 \mathrm{mg} / \mathrm{mL}$, DPBS, $\mathrm{pH} 7.4)$ was incubated with TFP-Alexafluor 488 ester $\left(40 \mu \mathrm{L}, 1 \mathrm{mg} / \mathrm{mL}\right.$ in DMF) at $4^{\circ} \mathrm{C}$ for $24 \mathrm{~h}$. The crude reaction was then purified by centriprep ultra-centrifugation (MWCO $3 \mathrm{kDa}$ against DPBS) to a final volume of $0.5 \mathrm{~mL}$. Degree of labeling studies were conducted by UV absorbance and it was found that Azide-GOX-AF488 contained 0.7 fluorophores per protein ( $280 \mathrm{~nm}$ protein, 490 nm dye) with a correlation factor of 0.11 .

\section{Fabrication and Enzyme Immobilization on Control Surfaces}

\section{Cross-Reactive Surface}

AO-PEG $(10 \mu \mathrm{L}, 1 \mathrm{wt} \%$ in $\mathrm{MeOH})$ was spin coated onto a piranha cleaned silicon wafer with gold alignment marks (4000 rpm, $1 \mathrm{~min}$ ). The wafer was then patterned by e-beam lithography as an array of $40 \mu \mathrm{m}$ boxes ( $23 \mathrm{~nm}$ spot size, $30 \mathrm{kV}$ accelerating voltage, $40 \mu \mathrm{C} / \mathrm{cm}^{2}$ area dose). The wafer was developed by immersion in Milli-Q water for 30 seconds, and patterns were confirmed using an inverted bright-field microscope. The wafer was subsequently spin coated (4000 rpm, $1 \mathrm{~min}$ ) with a solution of Alkyne-PEG (10 $\mu \mathrm{L}, 1 \mathrm{wt} \%$ in $\mathrm{MeOH})$. The surface wafer was then patterned by e-beam lithography ( $23 \mathrm{~nm}$ spot size, $30 \mathrm{kV}$ accelerating voltage, 20 
$\mu \mathrm{C} / \mathrm{cm}^{2}$ area dose) as an array of $40 \mu \mathrm{m}$ boxes patterned next to the existing AO-PEG features. The wafer was developed by immersion in Milli-Q water for 30 seconds, and patterns were confirmed using an inverted bright-field microscope. Next, Azide-GOX-AF488 $(20 \mu \mathrm{L}$ in DPBS $), \mathrm{CuSO}_{4}(10 \mu \mathrm{L}, 1 \mathrm{mg} / \mathrm{mL}$ in $10 \% \mathrm{DMSO})$, and sodium ascorbate $(10 \mu \mathrm{L}, 5 \mathrm{mg} / \mathrm{mL}$ in $10 \%$ DMSO) were exposed to the surface for $24 \mathrm{~h}$ before washing by immersion in $5 \mathrm{~mL}$ aliquots of $10 \%$ DMSO in DPBS 5 times for 30 seconds each. The wafer was then characterized by fluorescence microscopy.

\section{HRP Immobilized Surface}

AO-PEG $(10 \mu \mathrm{L}, 1 \mathrm{wt} \%$ in $\mathrm{MeOH})$ was spin coated onto a piranha cleaned silicon wafer (4000 $\mathrm{rpm}, 1 \mathrm{~min})$. The wafer was then patterned by e-beam lithography as an array of $40 \mu \mathrm{m}$ boxes (23 $\mathrm{nm}$ spot size, $30 \mathrm{kV}$ accelerating voltage, $40 \mu \mathrm{C} / \mathrm{cm}^{2}$ area dose). The wafer was developed by immersion in Milli-Q water for 30 seconds, and patterns were confirmed using an inverted bright-field microscope. Next, Lev-HRP-MB (40 $\mu \mathrm{L}$ in DPBS) was incubated with the surface for $24 \mathrm{~h}$ before washing by immersion in $5 \mathrm{~mL}$ aliquots of DPBS 5 times. Activity was assayed by adding the enzyme immobilized surface to a solution of hydrogen peroxide ( $300 \mathrm{ppm})$, and Amplex Red $(50 \mu \mathrm{M})$ in DPBS, $\mathrm{pH} 7.4$ and measuring the absorbance of resorufin at $560 \mathrm{~nm}$ after $2 \mathrm{~h}$ at $4^{\circ} \mathrm{C}$.

\section{GOX Immobilized Surface}

Alkyne-PEG (10 $\mu \mathrm{L}, 1 \mathrm{wt} \%$ in $\mathrm{MeOH})$ was spin coated onto a piranha cleaned silicon wafer (4000 rpm, $1 \mathrm{~min}$ ). The wafer was then patterned by e-beam lithography as an array of $40 \mu \mathrm{m}$ boxes (23 nm spot size, $30 \mathrm{kV}$ accelerating voltage, $20 \mu \mathrm{C} / \mathrm{cm}^{2}$ area dose). The wafer was developed by immersion in Milli-Q water for 30 seconds, and patterns were confirmed using an 
inverted bright-field microscope. Next, Azide-GOX-AF488 (20 $\mu \mathrm{L}$ in DPBS), $\mathrm{CuSO}_{4}(10 \mu \mathrm{L}, 1$ $\mathrm{mg} / \mathrm{mL})$, and sodium ascorbate $(10 \mu \mathrm{L}, 5 \mathrm{mg} / \mathrm{mL})$ were exposed to the surface for $24 \mathrm{~h}$ before washing by immersion in $5 \mathrm{~mL}$ aliquots of 10\% DMSO in DPBS 5 times for 30 seconds each. Activity was assayed by adding the enzyme immobilized surface to a solution of HRP $(1 \mu \mathrm{g})$, glucose $(10 \mathrm{mM})$, and Amplex Red (50 $\mu \mathrm{M}$ in DMSO) in DPBS, pH 7.4 and measuring the absorbance of resorufin at $560 \mathrm{~nm}$ after $2 \mathrm{~h}$ at $4^{\circ} \mathrm{C}$.

\section{PEG-OH Control Surface}

8-Arm poly(ethylene glycol) $(10.9 \mathrm{kDa}, 10 \mu \mathrm{L}, 1 \mathrm{wt} \%$ in $\mathrm{MeOH})$ was spin coated onto a piranha cleaned silicon wafer (4000 rpm, $1 \mathrm{~min}$ ). The wafer was then patterned by e-beam lithography as an array of $40 \mu \mathrm{m}$ boxes ( $23 \mathrm{~nm}$ spot size, $30 \mathrm{kV}$ accelerating voltage, $60 \mu \mathrm{C} / \mathrm{cm}^{2}$ area dose). The wafer was developed by immersion in Milli-Q water for 30 seconds, and patterns were confirmed using an inverted bright-field microscope. The wafer was first exposed to Lev-HRPMB (40 $\mu \mathrm{L}$ in DPBS), for $24 \mathrm{~h}$ before washing by immersion in $5 \mathrm{~mL}$ aliquots of DPBS, $\mathrm{pH} 7.4$, 5 times for 30 seconds each. Next, Azide-GOX-AF488 (20 $\mu \mathrm{L}$ in DPBS), $\mathrm{CuSO}_{4}(10 \mu \mathrm{L}, 1$ $\mathrm{mg} / \mathrm{mL})$, and sodium ascorbate $(10 \mu \mathrm{L}, 5 \mathrm{mg} / \mathrm{mL})$ were exposed to the surface for $24 \mathrm{~h}$ before washing by immersion in $5 \mathrm{~mL}$ aliquots of 10\% DMSO in DPBS 3 times for 30 seconds each. Activity was assayed by adding the enzyme immobilized surface to a solution of HRP (1 $\mu \mathrm{g})$, glucose $(10 \mathrm{mM})$, and Amplex Red $(50 \mu \mathrm{M})$ in DPBS, $\mathrm{pH} 7.4$ and measuring the absorbance of resorufin at $560 \mathrm{~nm}$ after $2 \mathrm{~h}$ at $4^{\circ} \mathrm{C}$.

\section{Alignment Wafer Control Surface}

A silicon wafer with gold alignment marks was cleaned by immersion in piranha solution. The wafer was subsequently incubated with Azide-GOX-AF488 (20 $\mu \mathrm{L}$ in DPBS, pH 7.4), and Lev- 
HRP-MB $(20 \mu \mathrm{L}$ in DPBS, $\mathrm{pH} 7.4)$ at room temperature for $3 \mathrm{~h}$. The surface was washed by immersion in $5 \mathrm{~mL}$ aliquots of DPBS, $\mathrm{pH} 7.4,5$ times. Enzyme removal from the surface was probed by adding $10 \mathrm{mM}$ glucose, $100 \mathrm{ppm}$ hydrogen peroxide and $50 \mu \mathrm{M}$ Amplex red to each wash mixture. No activity was observed in the $3^{\text {rd }}$ wash solution aliquot. Remaining activity on the surface was assayed by adding the bare alignment wafer surface to a solution of glucose (10 $\mathrm{mM})$, hydrogen peroxide (300 ppm), and Amplex Red $(50 \mu \mathrm{M})$ in DPBS, pH 7.4 and measuring the absorbance of resorufin at $560 \mathrm{~nm}$ after $2 \mathrm{~h}$ at $4^{\circ} \mathrm{C}$. 


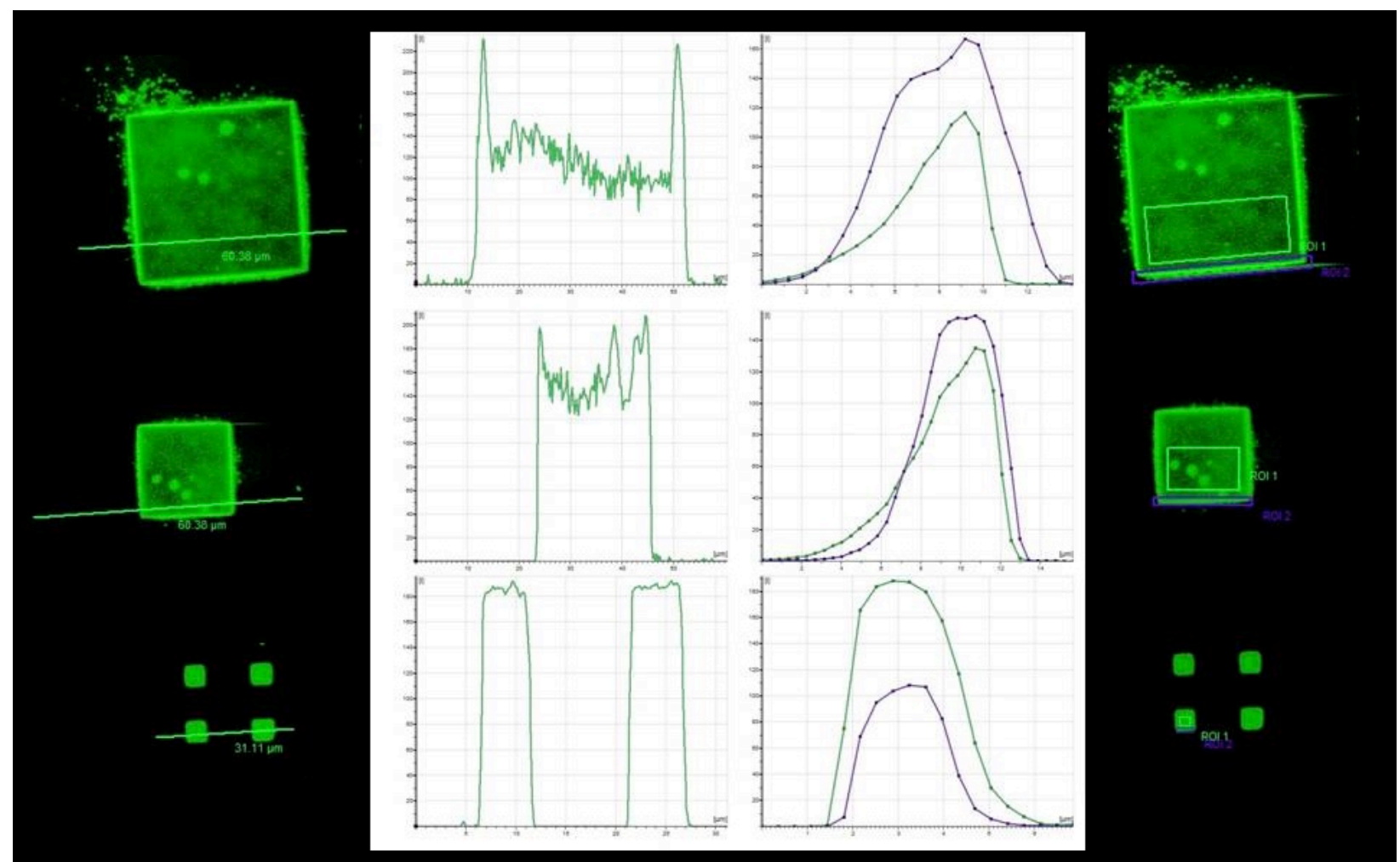

Figure S4. Effect of feature size on distribution of immobilized SAv -AF488 for a) $40 \mu \mathrm{m}$, b) $20 \mu \mathrm{m}$, and c) $5 \mu \mathrm{m}$ patterns of biotin-PEG hydrogels. 


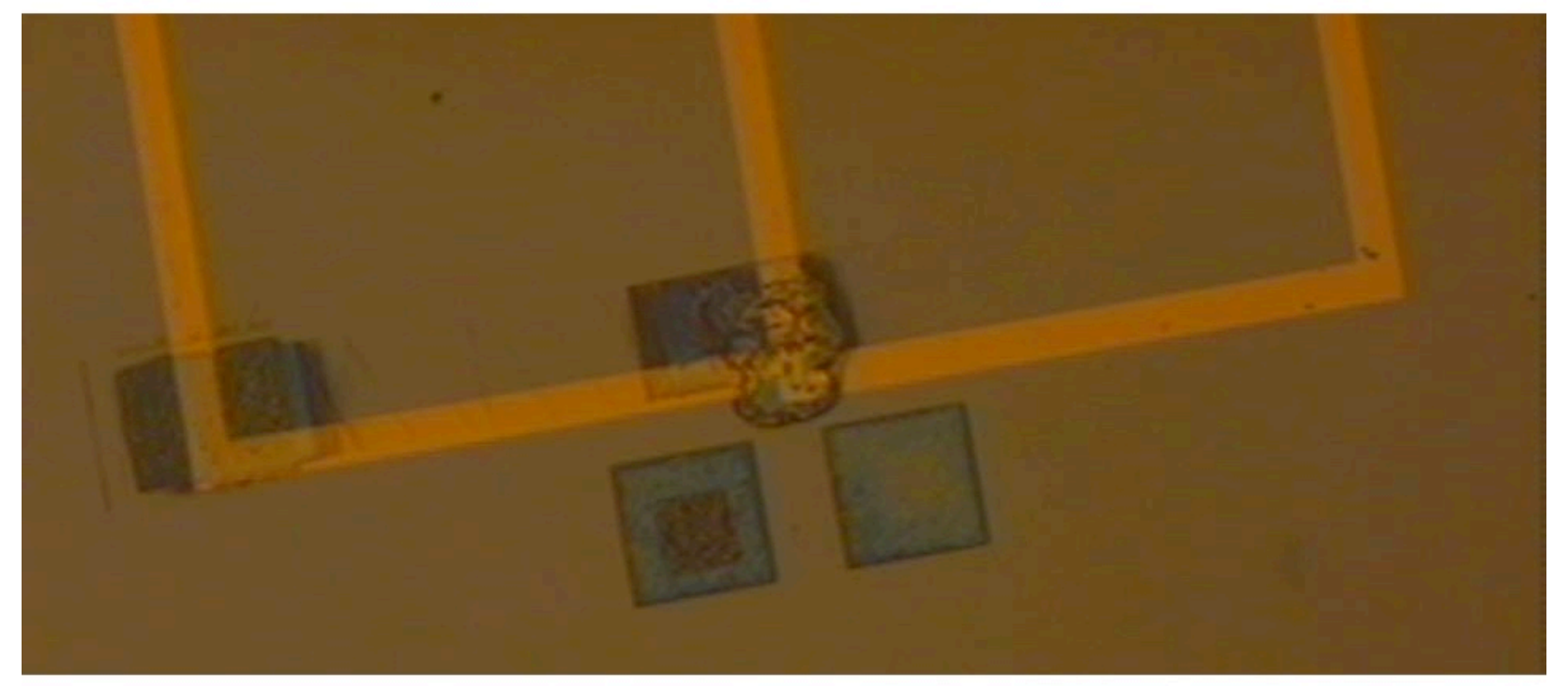

Figure S5. Bright-field microscope image (20x) of two PEG hydrogels patterned with encapsulated archetecture. The gold lines are the markings used for realignment during the three patterning steps in the lithography process employed to fabricate the multi-component hydrogels. 


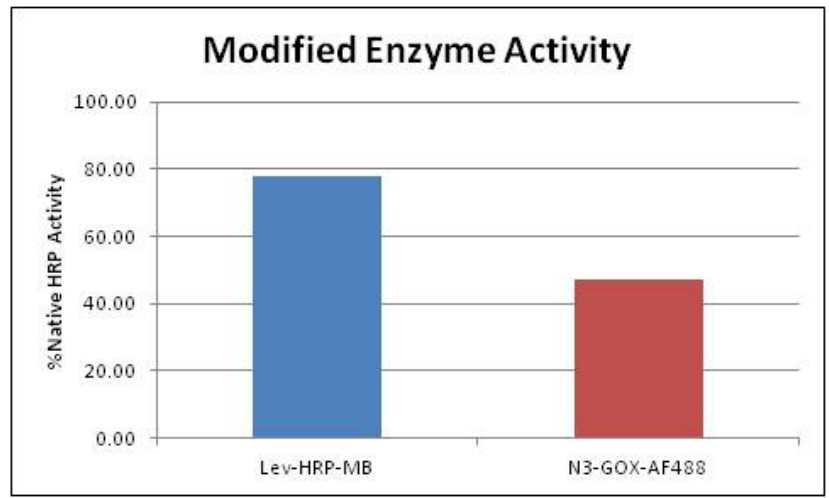

Figure S6. Horseradish peroxidase (HRP) and glucose oxidase (GOX) activity decreased by $32 \%$ and $53 \%$ respectively when modified. This graph shows enzyme activity of HRP treated with $N$-hydroxy succinimidyl levulinate ester followed by Marina Blue NHS ester (Lev-HRP$\mathrm{MB})$, and GOX treated with sulfonyl immidizole azide followed by Alexafluor 488 TFP ester (N3-GOX-AF488) relative to native HRP or GOX, respectively. 
a)

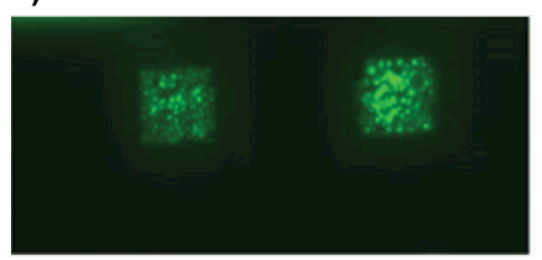

green channel b)

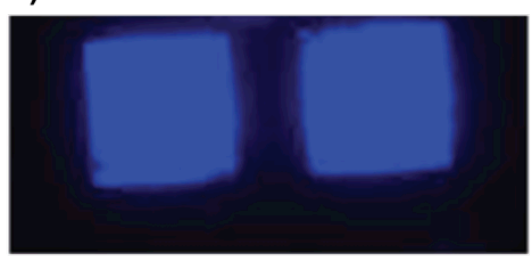

blue channel c)

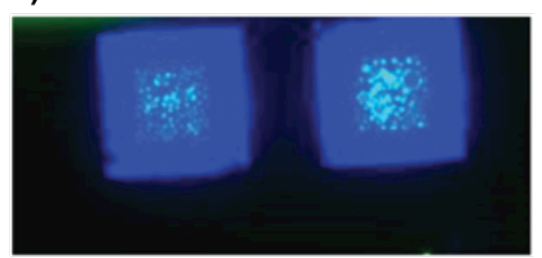

multi-channel

Figure S7. Fluorescent images of enzymes immobilized in the encapsulated architecture a) green channel, b) blue channel and c) multi-channel.

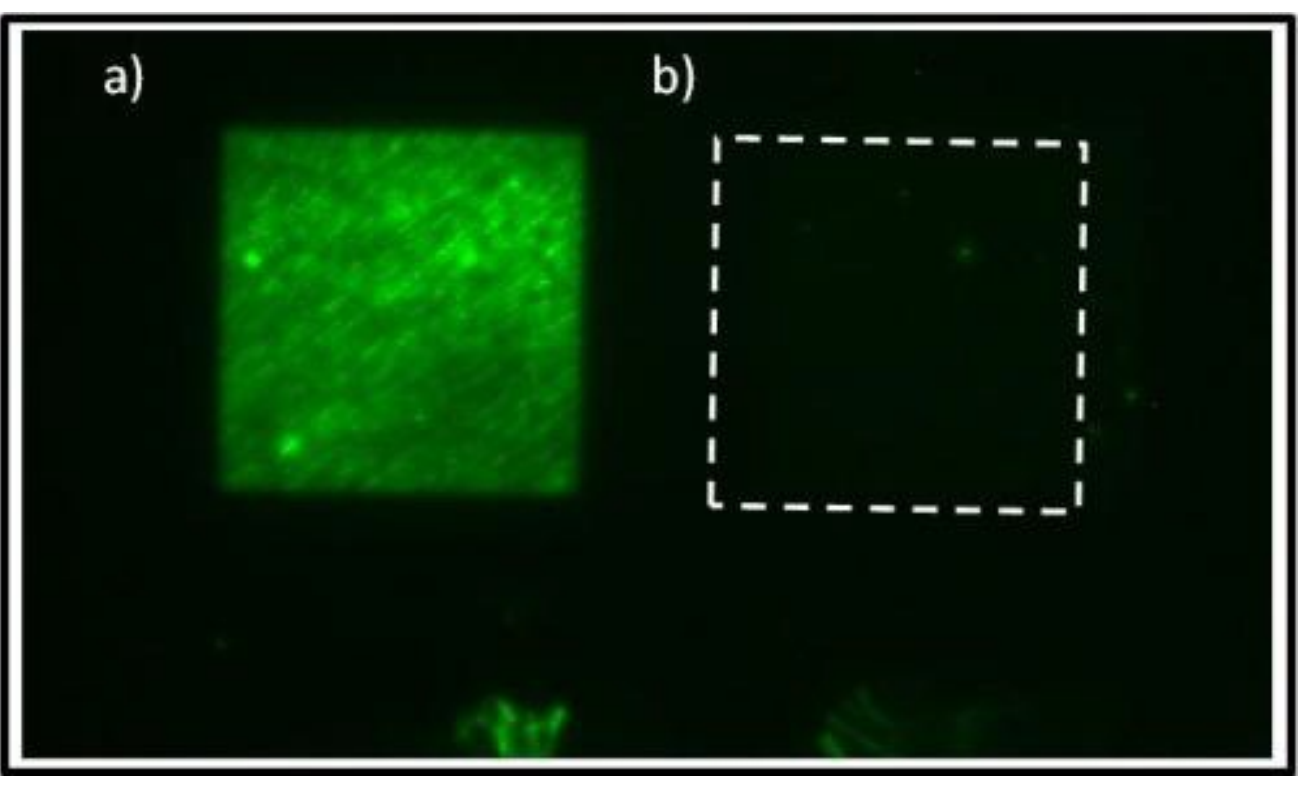

Figure S8. Cross reactivity showing minimal non-specific adsorption on side by side patterns. After incubation of the entire wafer with Azide-GOG-AF488, $\mathrm{CuSO}_{4}$, and sodium ascorbate with subsequent washings, a) a large increase in fluorescence is observed for the enzyme immobilized on Alkyne-PEG relative to b) AO-PEG Hydrogel is patterned within the white dashed box. Intensity difference is 38:1. 


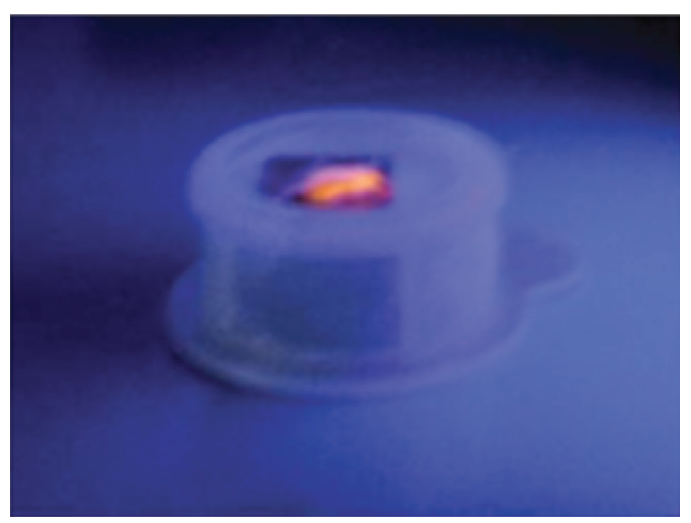

Figure S9. The silicon substrate mounted on a trans-well membrane with macroscopic evidence of enzyme activity.

\section{References Cited}

1. Christman, K. L.; Schopf, E.; Broyer, R. M.; Li, R. C.; Chen, Y.; Maynard, H. D. Positioning multiple proteins at the nanoscale with electron beam cross-linked functional polymers. J. Am. Chem. Soc. 2009, 131 (2), 521-527.

2. Goddard-Borger, E. D.; Stick, R. V. An efficient, inexpensive, and shelf-stable diazotransfer reagent: imidazole-1-sulfonyl azide hydrochloride. Org. Lett. 2007, 9 (19), 37973800.

3. Heredia, K. L.; Tolstyka, Z. P.; Maynard, H. D. Aminooxy end-functionalized polymers synthesized by ATRP for chemoselective conjugation to proteins. Macromolecules 2007, 40 (14), 4772-4779.

4. $\quad$ van Dongen, S. F. M.; Teeuwen, R. L. M.; Nallani, M.; van Berkel, S. S.; Cornelissen, J.; Nolte, R. J. M.; van Hest, J. C. M. Single-step azide introduction in proteins via an aqueous diazo transfer. Bioconjugate Chem. 2009, 20 (1), 20-23. 